\title{
Erratum to: Risk Factors Affecting Outcome of Metal-on-Metal Surface Arthroplasty of the Hip
}

Paul E. Beaulé MD, Fredrick J. Dorey PhD, Michel J. Le Duff MA, Thomas Gruen MS, Harlan C. Amstutz MD

Published online: 19 July 2011

(C) The Association of Bone and Joint Surgeons ® 2011

Erratum to: Clin Orthop Relat Res (2004) 418:87-93

In the original version of this article, which appeared in Volume 418, pages 87-93, the author listed as "Michel
LeDuff, MA" should be listed as "Michel J. Le Duff, MA".

P. E. Beaulé ( $₫)$, F. J. Dorey, M. J. Le Duff, T. Gruen,

H. C. Amstutz

David Geffen School of Medicine at UCLA, Joint Replacement

Institute at Orthopaedics Hospital, 2400 S. Flower St.,

Los Angeles, CA 90007, USA

e-mail: pbeaule@mednet.ucla.edu 